\title{
Assessment of energy-saving potential, associated costs and co-benefits of public buildings in Albania
}

\author{
Aleksandra Novikova $\cdot$ Zsuzsa Szalay $\cdot$ Miklós \\ Horváth • Johannes Becker • Gjergji Simaku • Tamás \\ Csoknyai (iD)
}

Received: 22 October 2019 / Accepted: 10 July 2020 /Published online: 13 August 2020

(C) The Author(s) 2020

\begin{abstract}
The paper presents the public building typology, energy demand estimations and retrofit scenarios, as well as associated costs and benefits for energysaving measures in the public building stock of Albania. First, representative building types were identified to estimate their energy performance, and define retrofit
\end{abstract}

Electronic supplementary material The online version of this article (https://doi.org/10.1007/s12053-020-09883-3) contains supplementary material, which is available to authorized users.

A. Novikova $\cdot$ J. Becker

Institute for Climate Protection, Energy and Mobility (IKEM),

Magazinstr. 15-16, 10179 Berlin, Germany

e-mail: aleksandra.novikova@ikem.de

e-mail: johannes.becker@ikem.de

\section{Z. Szalay}

Department of Construction Materials and Technologies, Faculty of Civil Engineering, Budapest University of Technology and Economics, Múegyetem rkp 3, Budapest 1111, Hungary

e-mail: szalay.zsuzsa@epito.bme.hu

M. Horváth · T. Csoknyai $(\bowtie)$

Department of Building Services and Process Engineering, Faculty of Mechanical Engineering, Budapest University of Technology and Economics, Müegyetem rkp 3, Budapest 1111, Hungary

e-mail: csoknyait@mail.bme.hu

M. Horváth

e-mail: horvath@epgep.bme.hu

G. Simaku

Ministry of Infrastructure and Energy, Sheshi "Skenderbej”, 1000 Tirana, Albania

e-mail: gjergji.simaku@gmail.com packages. Second, this information was used to analyse the costs and benefits of the different thermal efficiency retrofits. Apart from specific benefits due to cost savings in the use phase, co-benefits were estimated to understand their dimension and influence on decision-making. Finally, energy efficiency supply curves were developed to show the priority sequence of retrofits and building types. It was found that due to the growing wealth in Albania, user behaviour will change a lot in the future. Energy usage in the public building sector will increase and mitigate savings resulting from energy-saving measures making saved energy costs invisible. However, if other benefits beyond energy savings are considered, the cost efficiency of the measures remain obvious. The recommended approach can be used to assist decision-making and allocate funds.

Keywords Public buildings · Energy efficiency · Building typology · Bottom-up modelling - Supply curve of energy efficiency $\cdot$ Co-benefits

\section{Introduction}

Following a steep decline in the 1990s, Albania's economic growth reached $7.5 \%$ per year in 2008 (World Bank (online) 2016a). Economic growth declined in the years after the global financial crisis, but has been on the rise again since 2014 . In order to maintain the high rates of economic growth, Albania increasingly needs access to a long-term, secure, affordable and sustainable energy 
supply, and it has to use it in the most efficient and wisest way.

The energy demand in the building sector represents a special challenge. In 2015, the sector's final energy consumption was $37 \%$ of the national total (EUROSTAT 2017). Furthermore, the sector was responsible for $77 \%$ of electricity available for final energy consumption. The quality of energy services delivered in buildings is much lower than it is usually in the European Union. Most notably, Albanian public buildings are heated partially and only for a few hours a day particularly in the mild climate zones.

Albania is a contracting member of the Energy Community Treaty, and thus, it is obliged to introduce EU energy efficiency legislation. Addressing the targets and requirements of this legislation requires more ambitious policy efforts and larger investments into the demand-side energy efficiency than it occurs at present. Designing an intelligent policy package is not easy, however, due to the lack of understanding how to structure the building sector for policy making, how large the potential for energy saving is, where this potential is located and how much it costs to realise it. The first and only attempt to evaluate the energy-saving potential in the residential building sector of Albania was carried out by the SLED project (Novikova et al. 2018). However, no study on the public building sector exists.

The present publication aims to contribute to the evidence-based design of energy efficiency and climate mitigation policies in Albania that target the public building sector by providing the necessary information. The research presented here is the follow-up of the work elaborated for residential building stock in Albania, Montenegro and Serbia (Novikova et al. 2018). This paper addresses the following questions:

- How should the existing public buildings in Albania be classified? For each representative building type, what is the net and delivered energy by energy source for each thermal energy use?

- What are the possible retrofitting options and packages of options by representative building type? What are the investment costs per retrofitting measure and per building by representative building type?

- Which building types offer the largest and/or the most cost-effective energy savings? Do they pay back from energy cost savings?
- How significant are co-benefits of public building energy savings if they are monetised?

The paper is structured into five sections. After the "Introduction," a literature review discusses state-ofthe-art approaches for modelling energy efficiency policies in the building sector and advancements in this field in Albania. The "Methodology" section describes our approach, including main assumptions, equations and data sources, as well as research uncertainties. The next section presents and discusses the results of the assessment, and it also draws messages for policy- and decision-makers. Finally, the "Conclusion" summarises the key points of the paper.

\section{Literature review}

Approaches to model energy efficiency policies in the building sector

The modelling of energy systems is divided in the literature into top-down and bottom-up approaches. Top-down models examine interrelations between the macro-economic variables on the national level (e.g. unemployment rate, inflation, gross domestic product, energy price, etc.) and the energy consumption of the building sector. Bottom-up models on the other hand calculate the energy consumption of end uses of representative individual buildings, extrapolate the results for a geographical jurisdiction and therefore offer a higher level of detail and possibility to model technological improvement options. The cost is that bottom-up models' input data requirement is much greater than for top-down models (Novikova 2008). There has been a lot of work on the modelling of the residential building stock and on the estimation of its energy-saving potential (e.g. Ballarini et al. 2017; Brøgger and Wittchen 2018; Csoknyai et al. 2016; Dall'O' et al. 2012; Dascalaki et al. 2011; Dineen et al. 2015; Filogamo et al. 2014; Loga et al. 2016; Mata et al. 2015, 2014). The drawback of the bottom-up models is that the lack of data (e.g. related to user behaviour) compromises the accuracy of the model and validation is often lacking. To overcome these drawbacks, statistical and building physics-based models are combined into hybrid building energy models. These have been successfully applied, for example, for the Canadian housing stock 
(Swan and Ugursal 2009) and for the Danish residential building stock (Brøgger et al. 2019).

Related to this field of study, there have been only a few studies in the EU and its accession countries which calculate energy efficiency potential in the public sector using the bottom-up method. Specific examples for a successful application of bottom-up models are, for example, Korytarova et al. (2017) and Korytarova and Ürge-Vorsatz (2010); they calculated energy-saving potential of space heating in the public sector of Slovakia and Hungary. Paduos and Corrado (2017) compared the energy and economic feasibility of nearly zero-energy building solutions for the refurbishment of representative public buildings in 11 European countries. Ferrari and Beccali (2017) showed that up to $40 \%$ reduction of primary energy demand and emissions can be achieved with the energy retrofit of a building representative for the public building stock; however, an economic analysis highlighted many critical elements. Mikulić et al. (2016) estimated the impact of energy-saving investment in residential and public buildings in Croatia based on an input-output methodology. Direct, indirect and induced growth of added gross value, employment and government revenues, as well as the avoided costs of air pollution, was considered. Qu et al. (2017) analysed 14 public buildings in the severely cold region of China with the help of energy audit, statistics and costs. In the commercial sector, Kontokosta (2016) analysed the factors influencing the retrofit decisions in office buildings of nineteen U.S. cities from the CBRE, Inc. portfolio. Alves et al. (2018) developed a comprehensive framework for the analysis of the energy-saving potential of the high-rise office building stock of Brazil.

State of knowledge on the potential for energy savings in the building sector of Albania

Research about energy savings in the building sector of Albania is very limited. In order to show the state of knowledge, relevant studies and their main contents are mentioned in this section.

Within the project "Capacity building for Monitoring, Verification and Evaluation of the Energy Efficiency policy in SEE countries in terms of the EU accession process", energy supply and consumption are determined for the present state in the residential, public and private service sectors of Albania. The energy demand is forecasted for these sectors and energy efficiency targets are explained according to the National Action Plan on Energy Efficiency (NEEAP) and the Albania Energy Efficiency Plan (KEEP). As a result, monitoring indicators for energy efficiency measures were developed, while energy-saving potentials were only taken into account through experiences of different developed countries (GIZ 2011).

Different scenarios of energy developments were analysed in the study by the U.S. Agency for International Development (2015). This survey considers different scenarios of fuel availability, market penetration and energy efficiency developments.

Potential energy savings in the building stock in Albania are mentioned in Bidaj et al. (2015). This study determines the heating share of electricity consumption in households to point out multiple potentials. For instance, the results show that electric energy used for domestic hot water is the largest single electricity use among households, representing the largest share, at $22.7 \%$ of total electricity consumption. This suggests that the impact of higher penetration of solar panels for domestic hot water enables a big opportunity to raise energy efficiency in the building sector. The survey concludes that Albania's energy challenges can be viewed as opportunities to respond to the country's changing economic and climatic conditions with smart choices that provide Albanians with reliable and sustainable energy services. Therefore, policies and technical approaches are needed that consider how to address critical areas of energy use in Albania more sustainably (Bidaj et al. 2015).

It becomes clear that only very occasional specific potentials for energy savings are mentioned. The studies focus mostly on energy demand and scenarios on energy development in residential areas. In contrast, our paper focuses on the public building sector of Albania. The goal is to determine the energysaving potential of this sector by classifying existing public buildings and calculating the potential energy saving through different retrofit packages. A novelty is that besides the traditional financial analysis, an economic analysis with the monetisation of the cobenefits is also carried out. The latter is especially important to justify energy efficiency and mitigation policies because energy savings resulting from the application of energy efficiency measures are offset by the growing energy consumption making saved energy costs invisible. 


\section{Methodology}

\section{Research design}

The first step of our work was to construct a typology of the public buildings for Albania that had not existed before. To create it, the Albanian expert panel conducted surveys of existing public buildings, which served as the basis for creating the typology. Public buildings were classified into six categories according to the function of the building: dormitories, hospitals, kindergartens, offices, schools and universities.

The second step was to estimate the energy demand of each building type. For this purpose, energy audits were carried out in altogether forty-eight public buildings classified into the six types. Indicators, such as net energy need per building type and delivered energy per building type and energy source, were determined for each thermal energy use. Also for each building type, complex thermal efficiency retrofit options were defined and the associated energy saving were determined.

The third step was to analyse costs and benefits of thermal efficiency retrofits of Albanian public buildings at the country level. For this, traditional financial analysis was conducted based on the comparison of financial inflows and outflows taking into account capital investment and installation costs of retrofits, their maintenance costs, as well as saved energy costs. Furthermore, other benefits of thermal efficiency improvement beyond saved energy costs were also assessed and monetised for the country. These benefits include thermal comfort, avoided $\mathrm{CO}_{2}$ emissions, avoided economic effects from airborne pollutants, employment and economic growth. Finally, the analysis using the approach of energy efficiency supply curves was conducted to show visually the priority sequence of retrofits. In our case, a supply curve of energy efficiency characterised the potential energy savings from a set of thermal energy retrofit packages applied to different building types as a function of the cost per unit.

\section{Research boundaries}

Only thermal energy services delivered in the public buildings, namely space heating, space cooling, ventilation and water heating, were assessed. Other, excluded energy services consume a large share of the public sector balance, and therefore, it is important to keep in mind that building energy consumption would be higher if they would be taken into account.

The retrofit options included both the improvement of thermal envelope and the exchange of technical systems for water heating, space heating, ventilation and space cooling. The impact of climate change on space heating and cooling patterns was not considered. The building stock statistics, based on which the estimates were prepared, were dated as of 2012. The energy consumption was not calibrated to the sector energy balance at the national level. However, building energy demand is calibrated to energy bills of buildings audited; the ratios for measured to calculated consumption are presented in Annex 6. Buildings with electric heating are excluded from the table because heating energy consumptions were not measured separately from other uses (such as technological use), and thus, the values were not comparable. For some buildings, consumption bills were not available at all.

The estimates of the building stock

Based on the information provided by the Albanian expert panel, it was estimated that in 2012 the floor area of the main types of public buildings was 6.6 million $\mathrm{m}^{2}$. Out of that, $76 \%$ is occupied by the buildings used for educational purposes. Around 13\% of the floor area is occupied by offices and $11 \%$ by hospitals. The largest part of the public building floor area (57\%) was located in climate zone A (see Fig. 1). It was followed by climate zone B with $26 \%$ of this floor area and finally climate zone $\mathrm{C}$ with $17 \%$ of this floor area. The expert panel relied on the figures of the Albanian National Strategy of Energy (Republic of Albania 2003) updated based on the UNDP and Ministry of Economy Trade and Energy (2010). Based on the data series provided by statistical books of Albania, it was estimated that the floor area of the public sector has not changed significantly over the last years.

\section{Step 1. Building surveys}

Bottom-up modelling is usually based on a representative set of houses or in case of lack of data on a selection of real example buildings. The TABULA project that aimed at creating a harmonised structure for building typologies defined three approaches to classify building types (Loga et al. 2016): (1) real example building, (2) real average building and (3) synthetic average building. 

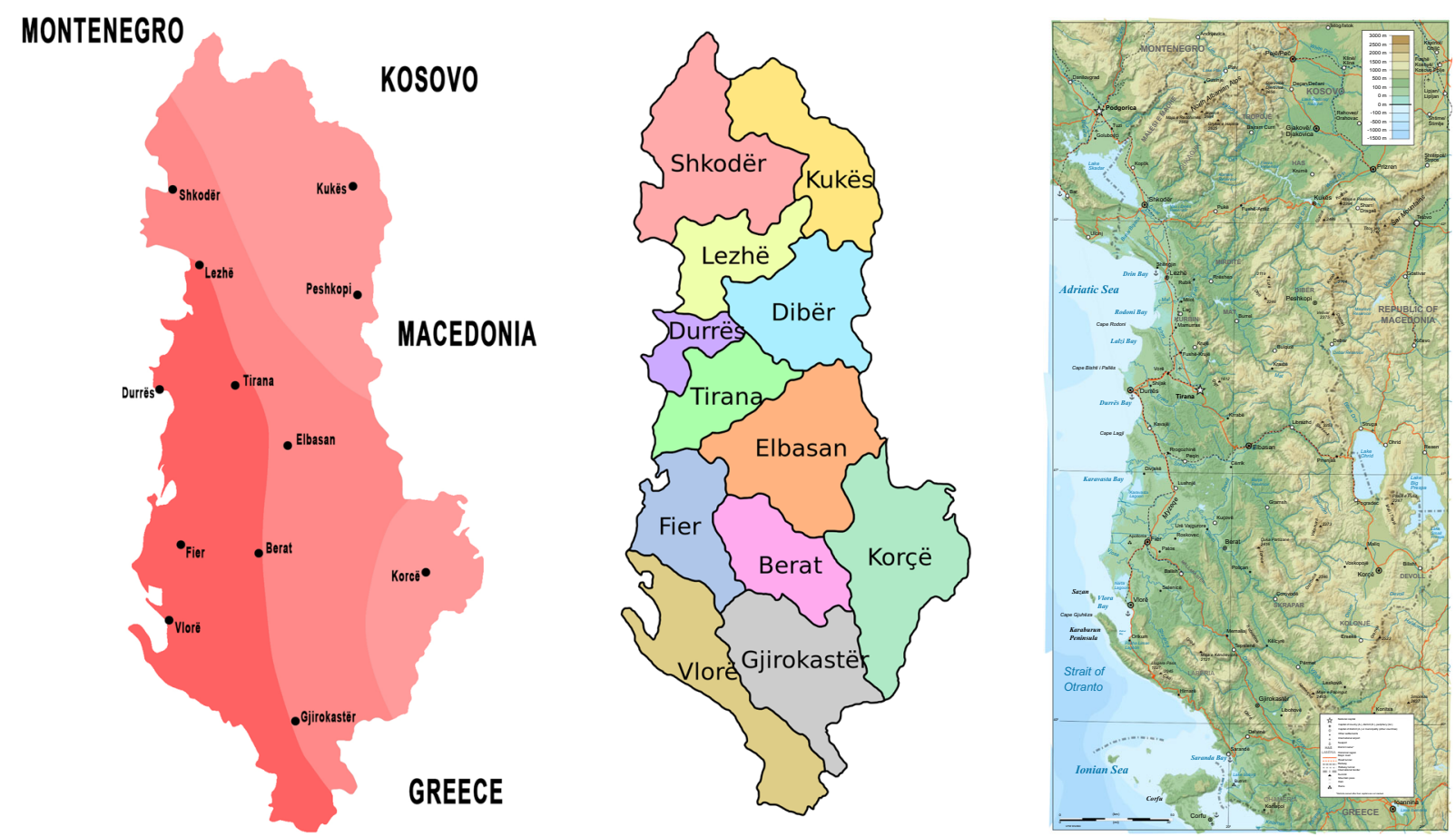

Fig. 1 Climate zones and prefectures in Albania (Simaku et al. 2014; Wikimedia 2018)

In this research, we applied the synthetical average building approach, a virtual building or an archetype that is a "statistical composite of the features found within a category of buildings in the stock" (IEA Annex 31 2004). This approach was selected because it enabled the most comprehensive reduction of uncertainties given the limited size of the available building sample - altogether, the Albanian expert panel surveyed forty-eight public buildings.

When selecting buildings to be surveyed, we were careful to include significantly different buildings with regard to the construction period, the size (small, medium and large buildings in each type) and the location of the building (from each climate zone). This ensured that buildings with different thermal characteristics were part of the survey. Table 1 presents the results of our selection of the main types of public buildings in Albania. The number of surveyed buildings was limited by the project budget. Certainly, it can be extended with further buildings in the future to improve model accuracy if further funds shall be allocated for this purpose. After the surveys, one synthetic average building was created for each building type, and the geometry parameters and the thermal values of this were defined as the mean values of the available sample. This approach was found to produce more reliable results than selecting just one representative building. For the technical building systems, the typical systems and their national share were determined by the local expert panel. Some surveyed buildings were very specific (e.g. under monumental protection) and, thus, were excluded from the average.

Construction characteristics, information about building envelope and technical systems of the surveyed buildings can be seen in the Electronic supplementary material (Annex 1, Annex 2 and Annex 3). The estimated duration of space heating and the share of heated floor area are provided in Table 2.

Step 2. Energy demand calculation method and main assumptions

\section{Climate data}

Albania was divided into three climate zones: zone A is the mildest along the coastline, zone $\mathrm{B}$ is the medium zone and zone $\mathrm{C}$ is the coldest in the mountainous region (Fig. 1). The Albanian regulations provided the heating degree days for the largest cities of Albania, but other climatic data are missing. By using the Meteonorm database and the PHPP software (Passive House Planning Package), information about other climate parameters, such as global, diffuse and direct radiation; air and 
Table 1 Characteristics of the main building types

\begin{tabular}{|c|c|c|c|c|c|c|c|}
\hline \multirow[t]{2}{*}{ Typology } & \multicolumn{3}{|c|}{$\begin{array}{l}\text { Surveyed buildings by } \\
\text { climate zone }\end{array}$} & \multirow[t]{2}{*}{ Size $\left[\mathrm{m}^{2}\right]$} & \multirow[t]{2}{*}{ Occupants/users } & \multirow[t]{2}{*}{ Construction period } & \multirow[t]{2}{*}{ Last renovation } \\
\hline & A & $\mathrm{B}$ & $\mathrm{C}$ & & & & \\
\hline Dormitories & 1 & 2 & 2 & $1300-4900$ & $74-518$ & 1950-1975 & $10-15$ years ago \\
\hline Hospitals & 1 & 2 & 2 & $2000-12,800$ & N/A & 1959-1987 & $\begin{array}{l}3 \text { hospitals: } 15 \text { years ago } \\
2 \text { hospitals: recently }\end{array}$ \\
\hline Kindergartens & 2 & 2 & 3 & $290-720$ & $100-200$ & 1960-1990 & In the last decade \\
\hline Public Offices & 1 & 2 & 4 & $110-1680$ & $9-104$ & 1952-1982 & $5-14$ years ago \\
\hline Schools & 3 & 2 & 12 & $1000-4000$ & $130-1160$ & $1950-2000$ & Some in 1990 , some in the last decade \\
\hline Universities & 1 & 6 & - & $740-5200$ & $350-2500$ & 1965-1979 & $5-10$ years ago \\
\hline
\end{tabular}

Source: author results. Note: For the definition of climate zones, please see "Step 2. Energy demand calculation method and main assumptions" section

dew point temperature; and wind speed, was collected. For climate zones $\mathrm{A}$ and $\mathrm{C}$, the parameters were corrected based on degree days provided by the Albanian regulations.

\section{Energy demand calculations}

The energy calculations included the thermal energy services, i.e. space heating and domestic hot water production, as well as space cooling and ventilation where relevant. Space heating and cooling energy need was calculated according to the quasi-steady-state seasonal method defined in EN ISO 13790 (2008). The method considers a sufficiently long period, which makes it possible to take into account the dynamic effects (storage and release of heat) by an empirically determined gain and/or loss utilisation factor.

The energy need for space heating and cooling were calculated by:

$$
\begin{aligned}
Q_{\mathrm{H}, \mathrm{nd}} & =Q_{\mathrm{H}, \mathrm{nd}, \mathrm{cont}}=Q_{\mathrm{H}, \mathrm{ht}}-\eta_{\mathrm{H}, \mathrm{gn}} \times Q_{\mathrm{H}, \mathrm{gn}} \\
& =\left(Q_{\mathrm{tr}}+Q_{\mathrm{ve}}\right)-\eta_{\mathrm{H}, \mathrm{gn}} \times\left(Q_{\mathrm{int}}+Q_{\mathrm{sol}}\right),
\end{aligned}
$$

and

$$
\begin{aligned}
Q_{\mathrm{C}, \text { nd }} & =Q_{\mathrm{C}, \mathrm{nd}, \mathrm{cont}}=Q_{\mathrm{C}, \mathrm{gn}}-\eta_{\mathrm{C}, \mathrm{ls}} \times Q_{\mathrm{C}, \mathrm{ht}} \\
& =\left(Q_{\mathrm{int}}+Q_{\mathrm{sol}}\right)-\eta_{\mathrm{C}, \mathrm{ls}} \times\left(Q_{\mathrm{tr}}+Q_{\mathrm{ve}}\right),
\end{aligned}
$$

where (for each building zone)

$Q_{\mathrm{H} / \mathrm{C} \text {,nd,cont }}$ is the building energy need for continuous heating/cooling $[\mathrm{MJ}]$;

$Q_{\mathrm{H} / \mathrm{C}, \text { ht }} \quad$ is the total heat transfer for the heating/ cooling mode [MJ];

$Q_{\mathrm{H} / \mathrm{C}, \mathrm{gn}} \quad$ is the total heat gains for the heating/ cooling mode [MJ];

$\eta_{\mathrm{H}, \mathrm{gn}} \quad$ is the dimensionless gain utilisation factor;

$\eta_{\mathrm{C}, \mathrm{ls}} \quad$ is the dimensionless utilisation factor for heat losses;

Table 2 Heated floor area and the duration of space heating by building type

\begin{tabular}{llll}
\hline Typology & Opening time [day/per annum] & Heating time [hours/day] & Heated floor area [\%] \\
\hline Dormitories & Some all year around, some close during summer months & $5-8$ & $45-80$ \\
Hospitals & All year & $10-20$ & $50-80$ \\
Kindergartens & 220 & $5-8$ & $65-90$ \\
Public Offices & 220 & $6-8$ & $35-80$ \\
Schools & $160-220$ & $4-5$ & $50-70$ \\
Universities & 220 & $4-8$ & $50-70$ \\
\hline
\end{tabular}

Source: author results 
$Q_{\mathrm{tr}} \quad$ is the total heat transfer by transmission $[\mathrm{MJ}]$;

$Q_{\mathrm{ve}} \quad$ is the total heat transfer by ventilation $[\mathrm{MJ}]$;

$Q_{\text {int }} \quad$ is the sum of internal heat gains over the given period $[\mathrm{MJ}]$;

$Q_{\text {sol }} \quad$ is the sum of solar heat gains over the given period [MJ].

Internal dimensions were used and corrected with the effect of thermal bridges as provided by the Albanian expert panel (Simaku 2016). For the calculation of solar gains, average orientation shading was assumed in winter $(80 \%$ reduction factor) and temporary external sun protection - in summer. The input data was based on the weighted mean values of the survey results.

As public buildings are usually not used all day around, correction factors for intermittent and partial heating (cooling) were introduced based on the number of heated (cooled) hours and the percentage of heated (cooled) floor area. A simplified method was applied for taking into account partial and intermittent heating/ cooling (see "Partial heating and cooling" section).

For building service systems, several options were calculated according to the heating system typical for the type of the building and the climate zone, detailed information is presented in Annex 2. In the baseline option, the energy demand of all building types was calculated for the climate of Tirana (climate zone B, as defined in the next section) and adapted the results to the other climate zones (climate zones A and C) by correction factors based on heating and cooling degree days.

\section{Partial heating and cooling}

For most buildings, consumption bills were available and have been analysed. In parallel, energy performance calculations were performed for each surveyed building. For many buildings, the calculated energy demand appeared to be higher than measured, which indicated insufficient heating of these buildings as compared to recommended health standards.

In Albania, typically, only a part of the building is heated to save energy and costs. Corridors, staircases, toilets and other secondary functions do not have heating at all, or the heating is not used in these areas (Simaku 2016). It is also typical for a heating system not to be turned on all day long, in order to save energy costs. Many public buildings have no central heating and especially cooling systems. Even if a central system exists, there is usually no automatic regulation.

Hence, a simplified method was applied for taking into account partial and intermittent heating (cooling) that multiplies the continuous heating (cooling) need with a correction factor based on the fraction of the heated (cooled) area and the fraction of the number of hours in the week with a normal heating (cooling) set point. These values were provided by the surveyors who asked questions about the normal use of the building; the values are presented in Electronic supplementary material Annex 5. The set-point temperature was assumed to be $20{ }^{\circ} \mathrm{C}$ for heating and $26^{\circ} \mathrm{C}$ for cooling, based on the survey results. The calibrated energy consumption values fit well with the measured values for the buildings where corresponding consumption data were available (Annex 6).

\section{Definition of retrofit options}

Two renovation options were developed for all building types, which consist of differently distinct measures for upgrading the building envelope and technical systems. Detailed information about thermal and technical upgrades, as well as specific boundary conditions for the retrofit options, can be seen in the supplementary material (Annex 2, Annex 3, Annex 4, Annex 5). The following descriptions of the retrofit options roughly summarise their qualities.

- The "business as usual" option (BAU improvement) included the renovation option most frequently applied at present — that is, most commonly the changing of windows, insulation of roofs and/or attic slabs, installing individual direct electric hot water heaters and low efficiency decentralised split cooling units in some of the rooms.

- The "efficiency" improvement option included a set of interventions for upgrades of the building envelope from an insulation point of view. In addition, efficient building service systems were introduced: reversible heat pumps with better coefficient of performance, efficient wood pellet boilers, lowtemperature gas boilers or efficient oil boilers. In terms of water heating, direct electric heating (as for BAU) or if not electric, combined systems with heating were applied. In heating zones A and B, no additional cost for cooling was assumed due to reversible heat pumps. In zone $\mathrm{C}$, the same simple 
cooling units were assumed as for BAU to keep the costs low.

Poor airtightness was considered due to leaky windows in the present state, resulting in excess infiltration in the winter. For the retrofit options, no excess infiltration was assumed due to the replacement of the windows.

In the future, it is predicted that the user behaviour will change. As the welfare of Albanian people is growing, the population will demand higher thermal comfort in public areas, in line with comfort levels of neighbouring countries. Therefore, public sector operators will have to heat and cool larger floor areas for a longer period of time and provide more domestic hot water, especially given that it is still not supplied in some public buildings.

In the retrofit options, an increase in the heated/cooled floor area and in the daily heated/cooled hours is therefore assumed, as well as higher hot water demand. The increase in these BAU comfort level was estimated in line with the current national trends as concluded in consultation with the Albanian expert panel based on the surveyors. In the efficiency option, the comfort levels are assumed to be even higher than the BAU levels, namely with heating and cooling of all relevant floor area for at least the minimum number of hours according to the health standards (for instance, daily heating hours of hospitals in climate zones A and B would grow from $8 \mathrm{~h}$ at present, to $12 \mathrm{in}$ the BAU case, and to $18 \mathrm{~h}$ in the efficiency option, whereas their heated floor area would grow from $58 \%$ at present, to $80 \%$ in the BAU case, and to $100 \%$ in the efficiency option). Specific values of the future development of intermitting and partial heating, cooling and ventilation can be seen in Electronic supplementary material Annex 5.

\section{System efficiencies}

Delivered (final) energy was calculated using the net heating energy demand $\left(Q_{\mathrm{ND}}\right)$ per energy source:

$Q_{\text {delivered }}=\frac{Q_{\mathrm{ND}}}{\eta_{\mathrm{t}}}$.

The system efficiency $\left(\eta_{t}\right)$ of the energy supply systems was calculated as follows:

$\eta_{\mathrm{t}}=\eta_{\mathrm{b}} \times \eta_{\mathrm{p}} \times \eta_{\mathrm{c}}$

where $\eta_{\mathrm{b}} \quad$ boiler (source) efficiency (defined by higher heating value)

$\eta_{\mathrm{p}} \quad$ piping (distribution) efficiency

$\eta_{\mathrm{p}} \quad$ control (regulation) and emission efficiency

Step 3. Economic and financial analysis

First, the traditional financial analysis was conducted based on the comparison of financial inflows and outflows related to the thermal efficiency retrofits of public buildings. The outflows were the associated costs, i.e. capital investment, installation and maintenance costs. The inflows were monetised benefits, which include saved energy costs.

Second, the first attempt to identify other benefits of thermal efficiency improvement beyond saved energy costs was made. These benefits included thermal comfort, avoided $\mathrm{CO}_{2}$ emissions, avoided economic effects from airborne pollutants, employment and economic growth.

Third, the analysis using the approach of energy efficiency supply curves was conducted. In our case, a supply curve of energy efficiency characterises the potential energy savings from a set of thermal energy retrofit packages applied to different building types as a function of the cost per unit. Comparing the cost of energy efficiency illustrated by the curve with energy prices allows prioritising energy-savings options or building types in terms of potential energy savings and their cost-effectiveness and suggests the investment schedule.

Financial analysis with consideration of saved energy costs

The traditional financial analysis was conducted in line with the methodology for public buildings as presented in EXERGIA (2013). It includes calculation of such indicators as investment size, simple payback period, net present value (NPV), internal rate of return (IRR) and the benefit-cost ratio:

- The investment size illustrates the total amount of incremental investment required for thermal efficiency improvement of public buildings.

- Simple payback period is the time required (in years) for the repayment of investment through its benefits (not discounted). 
- Internal rate of return is a discount rate that equates the present value of the expected outflows with the present value of the expected inflows.

- Net present value is a present value of the project cash flow over the measure lifetime.

- The benefit-cost ratio is the ratio between the net present value of benefits and costs.

The financial analysis was conducted based on real prices, i.e. not taking into account the inflation impact. The investment costs of technological options were estimated including the value added tax (and other taxes included in the price). The lifetime of retrofit packages was assumed to be 30 years in accordance with EU regulation 244/2012 (The European Commission 2012). The lifetime of the technical equipment was assumed to be 30 years for the packages, since in Albania most technical equipment are used past their lifetime.

The investment costs for the building envelope and service systems were provided by the Albanian expert panel per building type and measure. Prices include all system elements, although, depending on the present state of the building, there could be some additional work to remove the old installations. Prices include labour costs. For the national extrapolation, the prices to units per net floor area were transferred.

The applied technical building systems reflect the expected national energy mix of the corresponding retrofit level envisaged by the Albanian expert panel. As a consequence, the proposed technical solutions were not applicable for a single building (it was not realistic that the national energy mix was applied in one single building), but for a large number of buildings. In other words, this approach was suitable for the objectives of this work (national level extrapolation), but not for conceptual planning of single buildings.

The total specific retrofit costs were the summary of the costs for the building envelope refurbishment and that of the modernisation of the technical building system per net floor area unit (Table 3). On the top of these costs, the maintenance costs of $0.5 \mathrm{EUR} / \mathrm{m}^{2}$ floor area for "efficiency" retrofit had to be added.

The results of the financial (as well as the other two types of analyses) are highly dependent on the assumption of the discount rate. These in turn are highly dependent on a number of national circumstances and, most importantly, dependent on the chosen definition. In our assessment, a social discount rate of $4 \%$ was used as it was recommended by the European Commission ("European Commission" 2019).

There was no single source or agency which collects, reports and forecasts the dynamics of energy and fuel prices in Albania. Therefore, the current energy prices were gathered from different sources; when the information was missing, the best estimate was made. All future dynamics of energy was estimated as presented in Table 4.

\section{Economic analysis with the consideration of other benefits}

Improving energy efficiency is rarely a policy goal in its own right: it is rather used as a vehicle to arrive at other important social, political and economic ends. Some of the most frequently searched benefits of improved energy efficiency beyond saved energy costs are thermal comfort, reduced needs for energy, reduced exploitation on finite natural resources, health benefits, higher economic growth and the related reduction of GHG emissions. An attempt was made to include some of these important benefits into our analysis based on studies prepared for Albania and other countries with similar conditions.

Thermal comfort A big challenge for Albania is that at present the level of energy services delivered in public buildings is inadequately low. In case of BAU renovation of public buildings, the level of these services increases but remains low. In case of the "efficiency" renovation, it was assumed that Albania moved towards the level of thermal services which were in line with minimum health and comfort standards required by these facilities and typical for the European Union. It was assumed that due to higher thermal comfort provided in retrofitted buildings, their real estate value increases by $2 \%$ in total (Birleanu et al. 2013). The assumed estate value in BAU is EUR $300 / \mathrm{m}^{2}$ based on the statistics provided by the Albanian Statistical Office online (INSTAT).

Reduction in air pollution and health Energy efficiency improves air quality contributing to better public health (e.g. increased life expectancy, reduced emergency room visits, reduced asthma attacks, fewer lost work days and others) and avoidance of structural damage to buildings and public works. Birleanu et al. (2013) assessed and monetised the benefit of lower incidence of illness caused by air pollution. In line with this study, 
Table 3 Total investment costs per net floor area for all renovation options in all zones, EUR/m²

\begin{tabular}{|c|c|c|c|c|c|c|c|}
\hline \multicolumn{2}{|l|}{ Retrofit } & Dormitory & Hospital & Kindergarten & Office & School & University \\
\hline \multicolumn{8}{|c|}{ Climate zones A and B } \\
\hline \multirow[t]{3}{*}{ BAU } & Envelope cost & 1.60 & 1.35 & 4.36 & 1.80 & 2.05 & 0.76 \\
\hline & HVAC system cost & 0.81 & 0.96 & 0.83 & 0.83 & 0.80 & 0.80 \\
\hline & Total cost & 2.41 & 2.31 & 5.18 & 2.63 & 2.85 & 1.56 \\
\hline \multirow[t]{3}{*}{ Efficiency } & Envelope cost & 16.76 & 15.40 & 25.81 & 21.26 & 21.14 & 22.69 \\
\hline & HVAC system cost & 48.62 & 66.95 & 55.09 & 62.54 & 56.8 & 56.35 \\
\hline & Total cost & 65.38 & 82.35 & 80.90 & 83.80 & 77.94 & 79.04 \\
\hline \multicolumn{8}{|c|}{ Climate zone $\mathrm{C}$} \\
\hline \multirow[t]{3}{*}{ BAU } & Envelope cost & 1.60 & 1.35 & 4.36 & 1.80 & 2.05 & 0.76 \\
\hline & HVAC system cost & 0.85 & 0.80 & 0.88 & 0.88 & 0.80 & 0.80 \\
\hline & Total cost & 2.45 & 2.15 & 5.24 & 2.68 & 2.85 & 1.56 \\
\hline \multirow[t]{3}{*}{ Efficiency } & Envelope cost & 16.76 & 15.40 & 25.81 & 21.26 & 21.14 & 22.69 \\
\hline & HVAC system cost & 56.66 & 66.99 & 50.33 & 54.16 & 62.8 & 61.35 \\
\hline & Total cost & 73.42 & 82.39 & 76.14 & 75.42 & 83.94 & 84.04 \\
\hline
\end{tabular}

we assume that the avoided emissions of airborne pollutants result in benefits of EUR 1.38/MWh/year saved.

Climate change mitigation Energy savings result in a reduction of GHG emissions. Only $\mathrm{CO}_{2}$ emission reductions are calculated in our project. $\mathrm{CO}_{2}$ emission reductions could be also monetised applying a $\mathrm{CO}_{2}$ price. Based on Birleanu et al. (2013), it was assumed that $\mathrm{CO}_{2}$ cost increased from the current level to EUR $45 / \mathrm{tCO}_{2}$ in 2030. After this year, the $\mathrm{CO}_{2}$ price was kept constant.

Employment creation Most studies agree that energy efficiency investments will have positive effects on employment, by creating new business opportunities and thus jobs via domestically produced energy- efficient technologies and services, and through the economic multiplier effects of spending in other ways the money saved on energy costs. Further, a national policy that promotes both the production and the use of energy-efficient technologies helps all sectors of the country to compete internationally, thus contributing to economic development and job creation.

The researchers of the Arizona State University (2015) prepared an input-output model for Albania, based on which they estimated the impacts of converting Albanianschoolstogreenandenergyefficient. Thestudy assumed fourtiers ofbuilding improvement. Ourretrofit packages correspond to the combination of tiers 1,2 and 3 , and therefore, we used the proxies calculated from the impact of these tiers. Table 5 presents the proxies, which we used for the quantification of employment effects.

Table 4 Energy source prices

\begin{tabular}{llll}
\hline Energy sources & \multicolumn{2}{l}{ Price } & \\
\cline { 2 - 4 } & $2016[\mathrm{EUR} / \mathrm{kWh}]$ & $2045[\mathrm{EUR} / \mathrm{kWh}]$ & Annual growth $[\%]$ \\
\hline Electricity & 0.104 & 0.160 & $1.5 \%$ \\
Wood & 0.024 & 0.037 & $1.5 \%$ \\
LPG & 0.061 & 0.247 & $5 \%$ \\
Diesel oil & 0.117 & 0.473 & $5 \%$
\end{tabular}

Source: assumptions based on Enti rregullator I Energjisë (online) (n.d.), Global petrol prices (online) (n.d.), Szabo et al. (2015) and World Bank (online) (2016b) 
Table 5 Proxies for the quantification of multiplier effects for employment

\begin{tabular}{lll}
\hline Effect & Unit & Value \\
\hline Labour income & [EUR/EUR] & 0.30 \\
Direct & [EUR/EUR] & 0.17 \\
Multiplier effects & [EUR/EUR] & 0.13 \\
Annual employment & [jobs/million EUR] & 148 \\
Employment & [jobs/million EUR] & 85 \\
Multiplier effects & [jobs/million EUR] & 63 \\
\hline
\end{tabular}

Source: assumed based on Arizona State University (2015)

Economic growth One of the most important effects of thermal retrofit works is their contribution to the economic growth. Similar to employment effects, the experts of the Arizona State University also calculated the increase in value added due to retrofit works. Similarly, from this study, we calculated the proxies to make an estimate of multiplier effects for GDP due to thermal efficiency retrofits of the public sector. Table 6 presents the proxies, which were used for the quantification of GDP effects.

\section{Analysis using the supply curve method}

Usually, energy efficiency supply curves are prepared on a more granular level for a set of technological measures applied to each building type. In our case, the individual measures were merged into packages applicable to building types. This is because the technical possibilities in public buildings usually enable the implementation of complex measures.

The cost of energy efficiency $\left(\mathrm{CEE}_{j}\right.$, EUR/kWh) was estimated as:

$\mathrm{CEE}_{j}=\frac{\Delta \mathrm{AIC}_{j}-\Delta \mathrm{MC}_{j}}{\Delta \mathrm{FEC}_{j}}$,

where $\Delta \mathrm{AIC}_{j}$ is a difference in annualised investment and installation costs, $\Delta \mathrm{MC}_{j}$ is a difference in annual

Table 6 Proxies for the quantification of multiplier effects for GDP

\begin{tabular}{lll}
\hline Effect & Unit & Value \\
\hline GDP increase & {$[$ EUR/EUR] } & 0.65 \\
Direct & {$[$ EUR/EUR] } & 0.30 \\
Multiplier effects & {$[$ EUR/EUR] } & 0.35 \\
\hline
\end{tabular}

Source: assumed based on Arizona State University (2015) maintenance costs, $\Delta \mathrm{FEC}_{j}$ is a difference in final energy consumption and $j$ is a building type

$\Delta \mathrm{AIC}_{j}=a_{j} \times \Delta \mathrm{IC}_{j}$,

where $\Delta \mathrm{IC}_{j}$ is a difference in investment and installation costs and $a_{j}$ is the annuity factor.

$a_{j}=\frac{(1+\mathrm{DR})^{n_{j}} \times \mathrm{DR}}{(1+\mathrm{DR})^{n_{j}}-1}$,

where DR is the discount rate and $n_{j}$ is the technology lifetime.

Retrofit packages are cost-effective if the energy source price is greater than the cost of energy conserved.

\section{Results}

Energy calculation results

Figure 2 presents the results of our calculations for net energy demand of buildings at their present state by building type in all climate zones. The figure shows that space heating or domestic hot water (DHW) demand is the most important thermal energy uses, but the picture strongly depends on the building type since the service equipment differs so much. In between the climate zones of one building type, heating energy demand increases most significantly from A to $\mathrm{C}$, whereas DHW and cooling energy almost stay the same, except for zone $\mathrm{C}$ where no cooling is provided at all.

The highest energy demand belongs to hospitals and dormitories, because of the high DHW demand. The heating energy demand is also high in these building types, because of the more than double weekly heated hours than those for schools and universities. In general, it can be stated that in the present state the users' profiles have a higher influence on the energy demands than the buildings themselves. However, it should be noted that if comfort demands increase in the future, the energy demands will be significantly higher (Simaku 2016) and this situation may change. All values related to users' habits applied in the model have been determined by the Albanian expert panel (Simaku 2016).

Figure 3 presents the results of our calculations for net energy demand of the three types of buildings at their present state, BAU and efficiency improvements for climate zones $\mathrm{A}$ and $\mathrm{C}$. The figure attests that even though the performance of the building envelopes and 


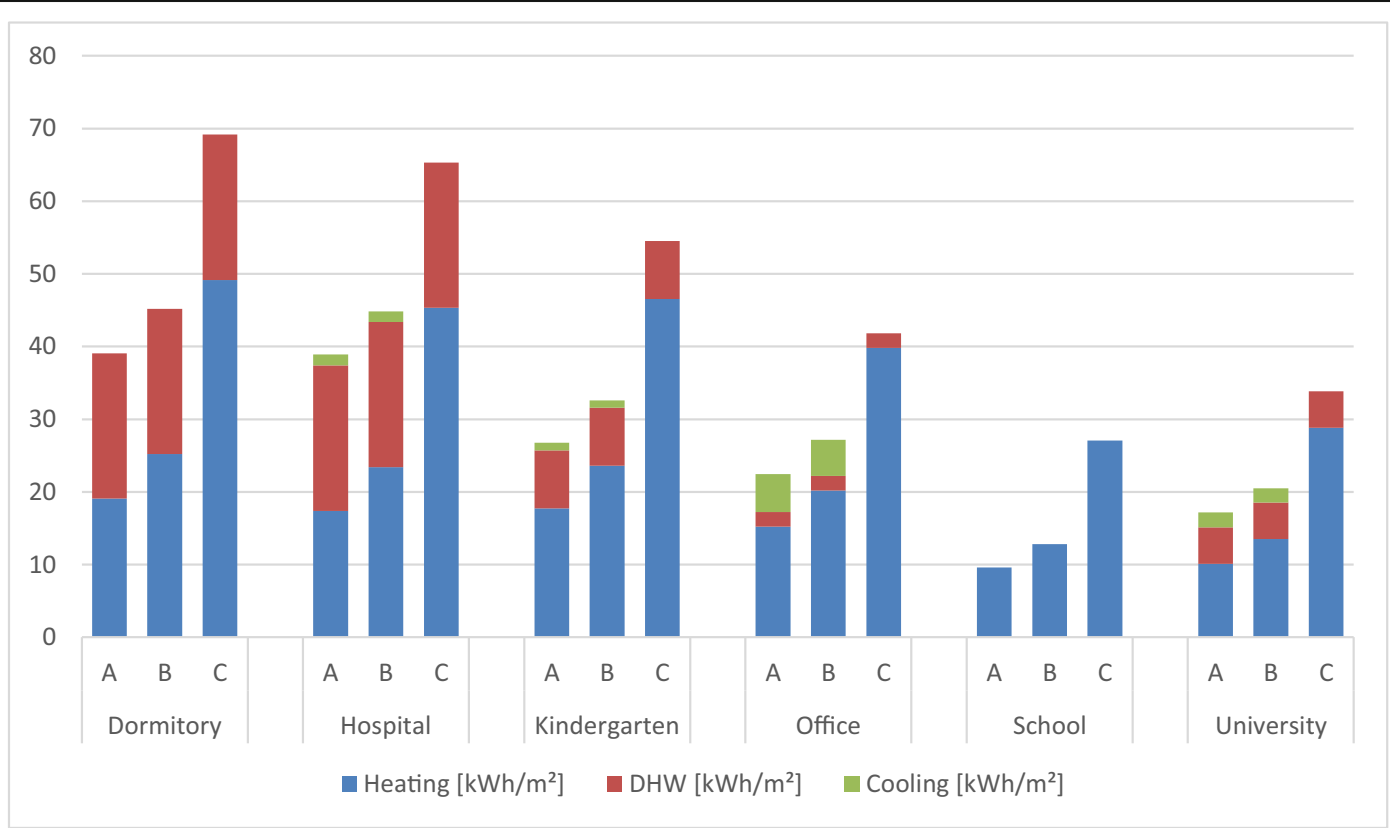

Fig. 2 Net energy demand of building types, $\mathrm{kWh} / \mathrm{m}^{2}$ year (present state). Note: $\mathrm{A}, \mathrm{B}$ and $\mathrm{C}$ are the climate zones

the technical building systems is better in retrofit options than at the present state, the energy demand is higher. This phenomenon is a result of the higher number of heated, ventilated and cooled hours; larger heated and cooled floor area; higher water demand; and the provision of hot water in building types where originally there was no DHW at all in the retrofitted buildings as compared to their present state. This is particularly notable for BAU renovation, where only minor energy efficiency measures are taken, but the comfort level rises.

Figure 4 presents the results of our calculations for final energy with its breakdown by energy carrier for three types of buildings at their present state, BAU and efficiency improvements for climate zones A and C. For both the present and retrofit packages, we used energy mix estimates provided by the Albanian expert panel. Our calculations reveal that at the country scale, in climate zone A, the most important energy source is electricity, while in climate zone $\mathrm{C}$, it is wood. The detailed results of energy calculations can be found in Annex 6 and Annex 7.

In Figs. 3 and 4, only climate zones $\mathrm{A}$ and $\mathrm{C}$ are taken into account, since they represent the most extreme and opposing weather conditions and therefore the most extreme energy demand. In terms of building types, the figures focus on hospitals, kindergartens and schools, as they represent the biggest share of the public building stock in Albania.
Traditional financial analysis

One of the most common reasons for conducting thermal efficiency in buildings is to save on energy bills. In this regard, there are two challenges how to make the right estimates of energy cost savings. This is, first, how to make the right assumption about the amount of energy demand given current low standards of living and their improvement in the future and, second, how to make the right assumption about the expected energy prices (the latter was already presented in the "Financial analysis with consideration of saved energy costs" section).

As discussed in the previous chapter, the efficiency improvement assumed higher levels of thermal services than the current levels or those observed in case of the BAU retrofits. Having higher energy service levels in case of efficiency renovation makes energy savings much smaller, but it is the reality of Albania increasing its welfare. In order to make the efficiency retrofit package comparable with the BAU renovation, the country-wide financial and economic analyses were prepared according to the level of comfort for the BAU renovation as it is in the efficiency improvement. Further, all calculations and results are reported using this assumption and compare the results of calculations between BAU and efficiency retrofits. 


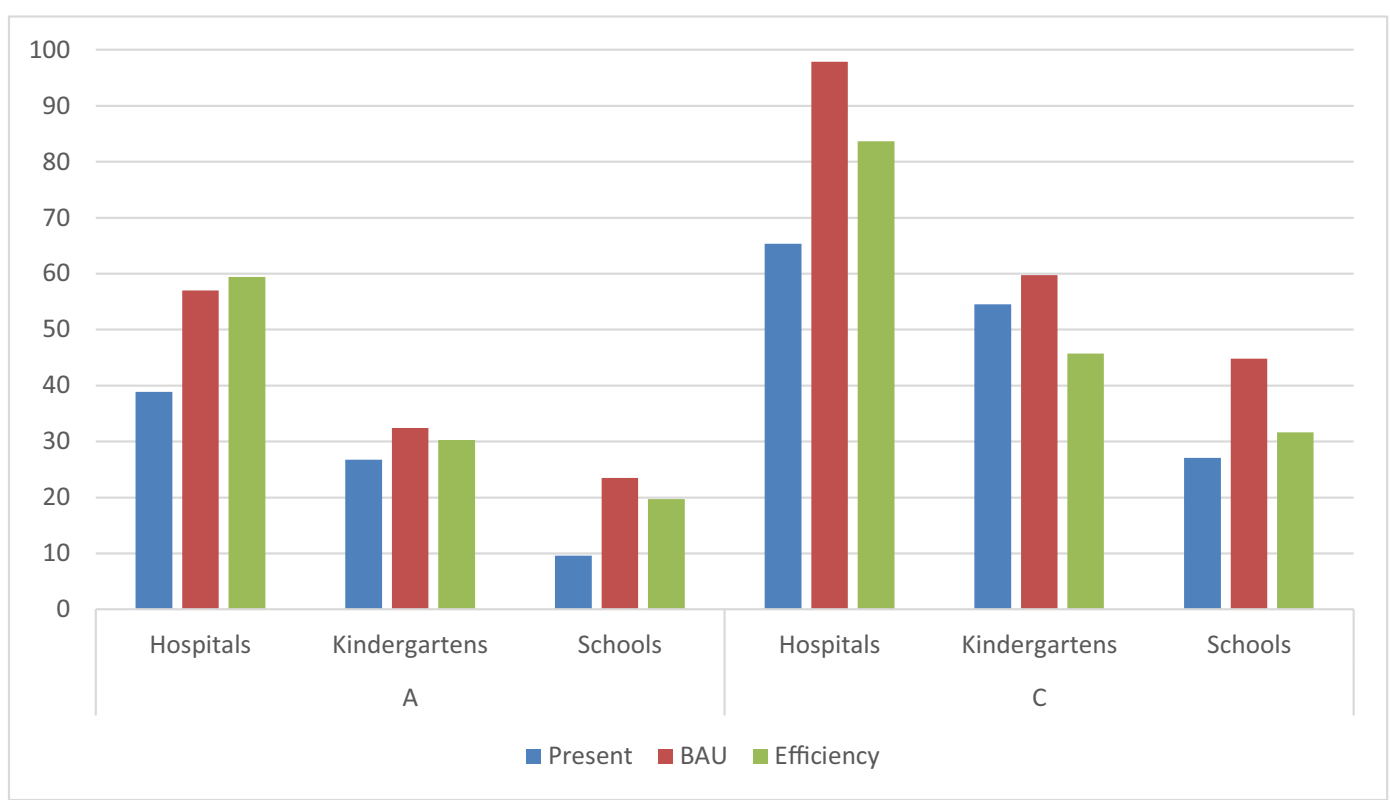

Fig. 3 Net energy demand of building types, $\mathrm{kWh} / \mathrm{m}^{2}$ year (partial and intermittent heating) for climate zones A and C

Figure 5 presents the final energy savings by building type and climate zone for the "efficiency" retrofit at a country level as compared to the BAU retrofit. The figure attests that the highest final energy demand savings per square meter are observed in the buildings of climate zone $\mathrm{C}$. These indicators are twice smaller for climate zones $\mathrm{A}$ and $\mathrm{B}$, the difference between which is not so significant. The highest final energy demand savings per square meter are in dormitories, hospitals and offices in different ranking order among climate zones. Climate zone A locks the largest share of final energy savings in absolute values because of the larger number of buildings than in climate zone $\mathrm{C}$.

Table 7 presents the costs of retrofits by building type and climate zone for the "efficiency" retrofit, which are already additional to the BAU retrofit costs. The table

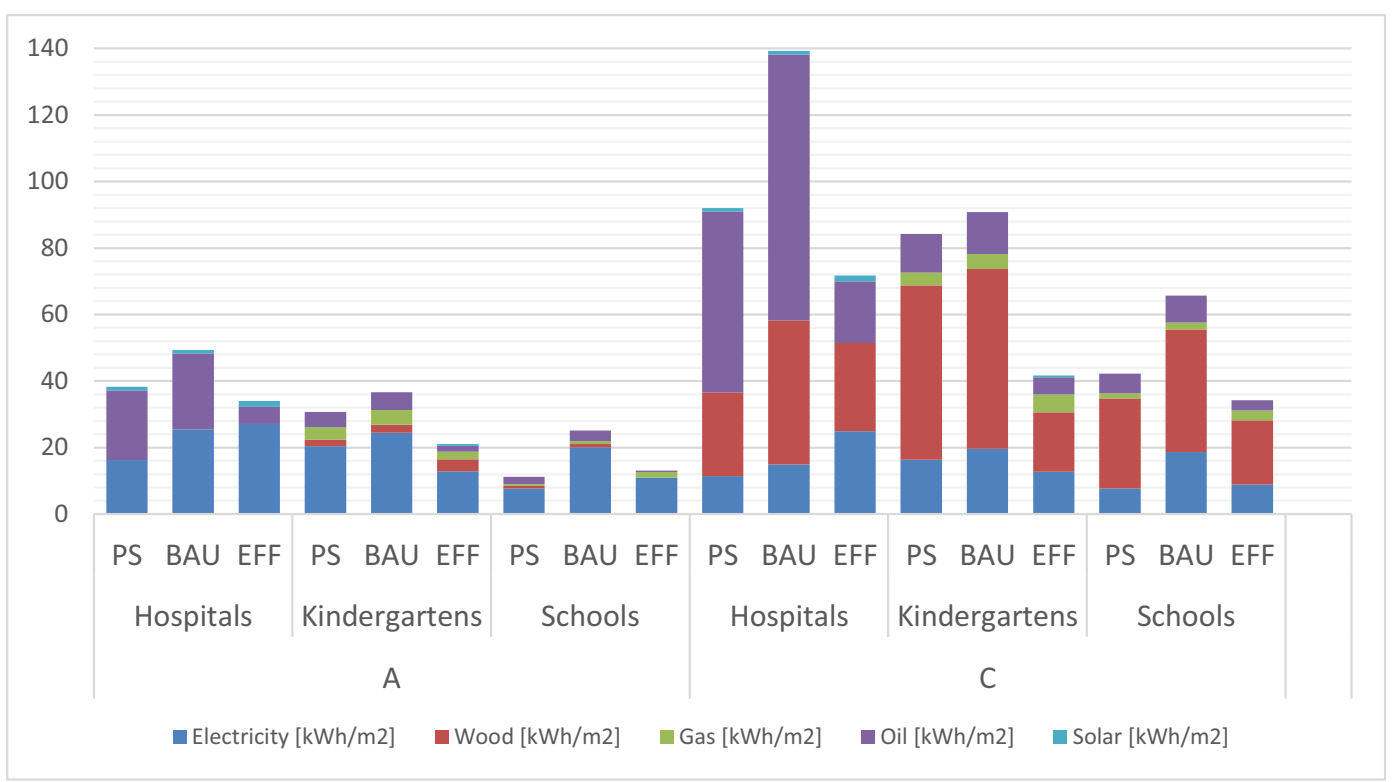

Fig. 4 Final energy of building types in climate zones $\mathrm{A}$ and $\mathrm{C}(\mathrm{PS}=$ present state, $\mathrm{BAU}=$ business as usual improvement, $\mathrm{EFF}=\mathrm{efficiency}$ improvement) 


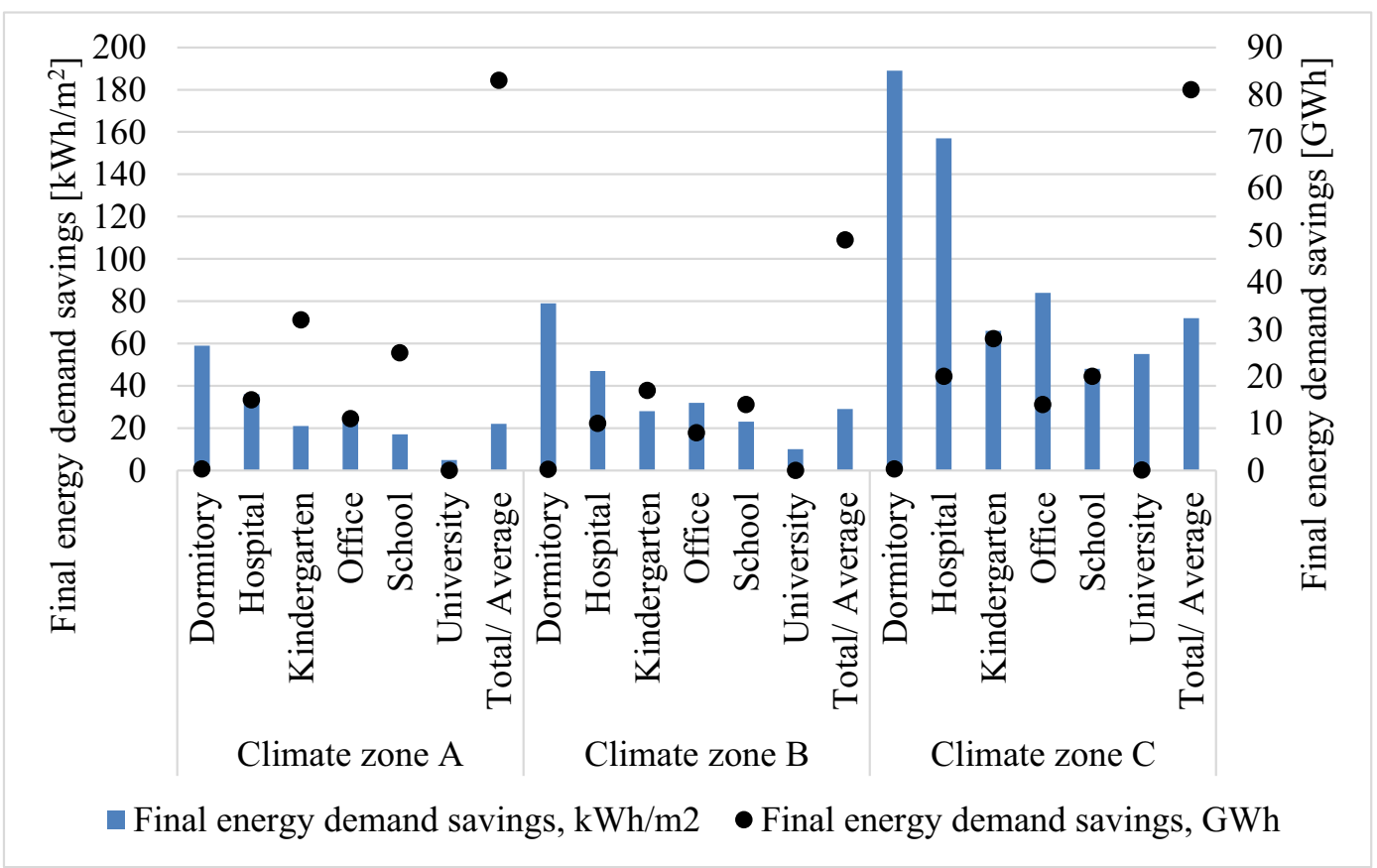

Fig. 5 Final yearly energy demand savings by building type and climate zone, the "efficiency" retrofit compared to the BAU retrofit

illustrates that investment costs per square meter are the lowest among building types for dormitories, followed by kindergartens and schools. The differences between climate zones are not significant. In order to retrofit all Albanian public buildings to the level of the "efficiency" retrofit, ca. EUR 500 million is needed. The building types requiring the highest investment on the national scale are kindergartens and schools followed by offices and hospitals. If classified by climate zone, the largest investment is required in climate zone A.

Figure 6 presents saved energy costs per square meter by building type and climate zone in case of the "efficiency" retrofit. The figure attests that the highest energy cost savings per square meter are offered by hospitals and dormitories. The largest absolute energy cost savings could be achieved in kindergartens, schools and hospitals. Saved energy costs per square meter in climate zone $\mathrm{C}$ are more than twice higher than those in climate zone A and they are $65 \%$ higher than those in climate zone B. The average energy savings over lifetime are approx. $4.4 \mathrm{EUR} / \mathrm{m}^{2}$ annually or $76 \mathrm{EUR} / \mathrm{m}^{2}$ over the whole lifetime. The figure shows that the total energy cost savings are EUR 29 million/year or EUR 500 million over the lifetime. Almost $45 \%$ of it is in climate zone A due to its large number of buildings.

Table 8 presents the results of the financial analysis aggregated across all climate zones at a country level. The table shows that the retrofits of universities are not financially feasible if only saved energy costs are taken as benefits (the payback time higher than the measure lifetime, the cost-benefit ratio is higher than 1, NPV is negative, IRR is negative). The retrofits of schools and kindergartens also are not financially attractive (negative NPV, the cost-benefit ratio is higher than 1). Dormitories and hospitals are financially feasible for retrofits, whereas offices are on the edge of feasibility.

Economic analysis including co-benefits

Table 9 presents the results of monetising other benefits of thermal efficiency retrofits than energy cost savings over the lifetime of retrofit packages. The table illustrates that these benefits (EUR 534 million over measure lifetime and ca. 75 thousand jobs) are cumulatively comparable to saved energy costs. Especially high are effects on GDP and employment. It should be noted that we quantified only a limited number of co-benefits. If all of these benefits are taken into account in the financial analysis, the cost-effectiveness of thermal efficiency retrofit of all types of public buildings would be much higher. 
Table 7 Saved energy costs by building type and climate zone, the "efficiency" retrofit

\begin{tabular}{|c|c|c|c|c|c|c|c|}
\hline Building type & Dormitory & Hospital & Kindergarten & Office & School & University & Total \\
\hline \multicolumn{8}{|c|}{ Annual over measure lifetime, EUR $/ \mathrm{m}^{2}$} \\
\hline Average & 12.3 & 11.2 & 3.7 & 4.6 & 2.9 & 2.2 & 4.4 \\
\hline Climate zone A & 9.6 & 7.5 & 3.2 & 3.5 & 2.4 & 1.1 & 3.4 \\
\hline Climate zone B & 12.6 & 9.5 & 4.2 & 4.6 & 3.1 & 2.0 & 4.5 \\
\hline Climate zone $\mathrm{C}$ & 21.2 & 26.7 & 4.8 & 7.7 & 4.1 & 6.5 & 7.4 \\
\hline \multicolumn{8}{|c|}{ Total over measure lifetime (NPV), million EUR } \\
\hline Total & 1.90 & 147 & 163 & 68 & 122 & 0.42 & 502 \\
\hline Climate zone A & 0.9 & 55.1 & 83.1 & 27.0 & 60.6 & 0.12 & 227 \\
\hline Climate zone B & 0.5 & 34.1 & 45.2 & 19.6 & 32.4 & 0.09 & 132 \\
\hline Climate zone $\mathrm{C}$ & 0.5 & 58.1 & 34.5 & 21.7 & 28.6 & 0.2 & 144 \\
\hline
\end{tabular}

Analysis using the supply curve method

Comparing the cost of energy efficiency with energy prices helps to identify the priority measures in the public sector for policy makers. If we compare the cost of energy efficiency calculated with the current electricity price $(0.104 \mathrm{EUR} / \mathrm{kWh})$, the retrofits in all building types except for schools of climate zone $\mathrm{C}$ as well as the retrofits of dormitories in climate zones $\mathrm{A}$ and $\mathrm{B}$ are cost-effective (Fig. 7). If the electricity price will grow as it was assumed, the retrofits of all building types in climate zone $\mathrm{C}$ as well as dormitories and hospitals in climate zone B will become cost-effective. Similar conclusions could be also drawn comparing the cost of energy conserved with other energy prices.

Figure 8 presents the cumulative potential for final energy savings as a function of the cost of energy efficiency for the whole country. The figure illustrates that building types which cumulatively are able to supply the largest potential are kindergartens, schools and hospitals. Offices also offer large potential for energy savings. If all retrofits in the country will be conducted,

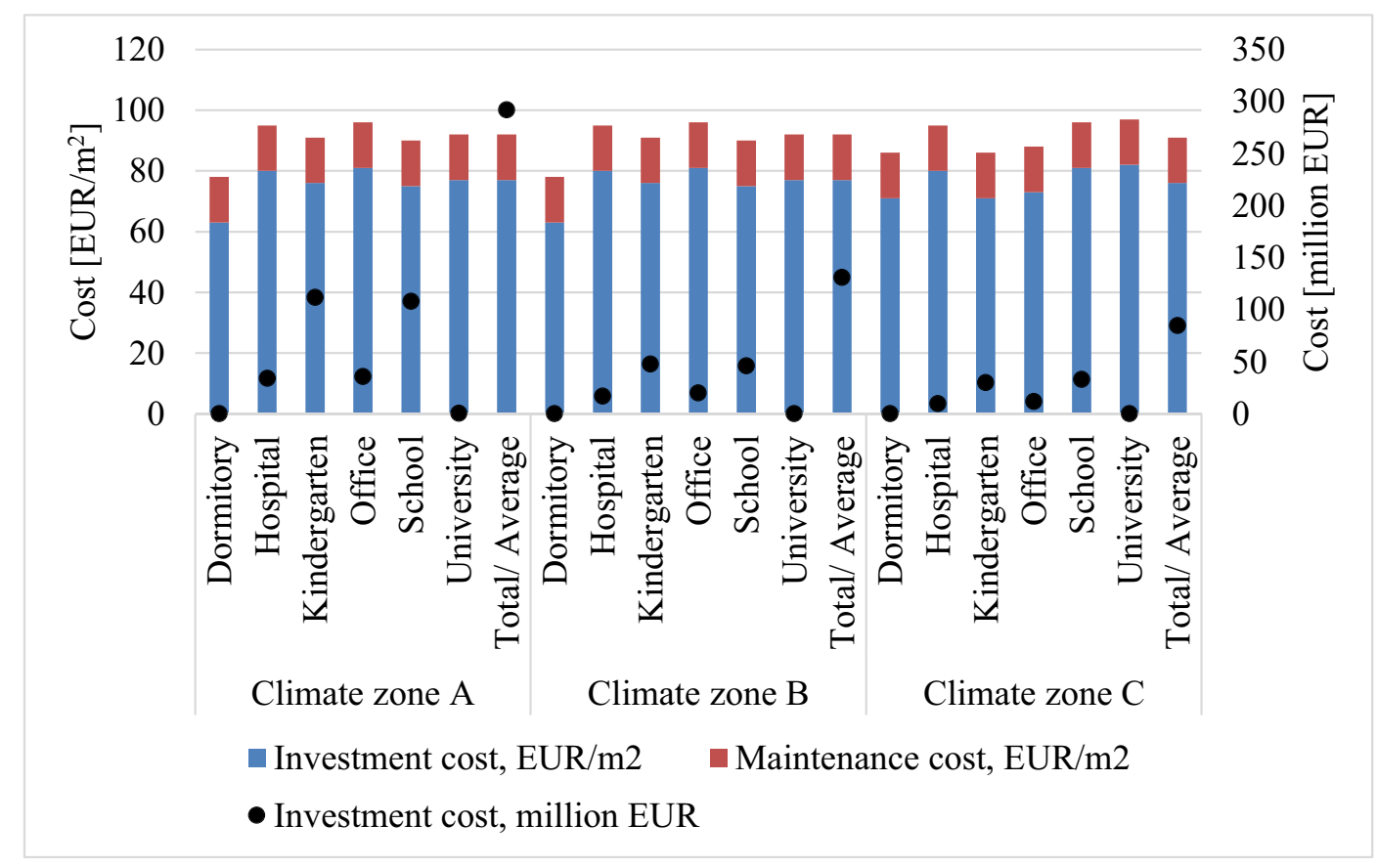

Fig. 6 Costs of thermal energy efficiency retrofits by building type and climate zone, the "efficiency" retrofit 
Table 8 Financial analysis, the "efficiency" retrofit

\begin{tabular}{|c|c|c|c|c|c|c|c|}
\hline Financial analysis & Dormitory & Hospital & Kindergarten & Office & School & University & Total \\
\hline Simple payback, years & 5 & 7 & 20 & 17 & 27 & $\mathrm{n} / \mathrm{a}$ & 17 \\
\hline Internal rate of return (IRR), \% & $15.7 \%$ & $11.1 \%$ & $3.0 \%$ & $4.0 \%$ & $1.1 \%$ & $-0.2 \%$ & $3.9 \%$ \\
\hline Net present value (NPV), EUR $/ \mathrm{m}^{2}$ & 1.3 & 83.2 & -25.8 & 0.2 & -63.3 & -0.4 & -4.8 \\
\hline Cost-benefit ratio & 0.3 & 0.4 & 1.2 & 1.0 & 1.5 & 2.1 & 1.0 \\
\hline
\end{tabular}

it will help save approximately $210 \mathrm{GWh} /$ year. If only those retrofits would be conducted, which cost is less than $0.1 \mathrm{EUR} / \mathrm{kWh}$, then approximately $62 \mathrm{GWh} /$ year could be saved.

\section{Discussion and policy implications}

Design options of the public sector energy efficiency program

According to the law 124/2015 "On Energy Efficiency", an energy efficiency fund is going to be established as an independent organisation governed by a governmentappointed board of governors or board of trustees comprising both public sector and private sector members. The analysis presented, even simplistic, can help the stakeholders involved to make their decisions. These are policy makers at the state and local levels, energy service companies (ESCOs), developers, architects, designers, contractors, suppliers/manufacturers, inspectors, auditors, building maintenance/operators and clients/users as well as the donors providing financing to Albania.

The amount of financing depends on the available local and international funding and expected demand. In the 2nd and 3rd NEEAP, the following indicative budget was assumed for the period 2017-2020 (Table 10).
There are several approaches to the distribution of these funds. These could be, for instance, according to the breakdown of building stock by type or according to the size of the potential that makes it easier to apply standardised methodologies, according to the costeffectiveness of investment and according to the scale of other benefits, e.g. social benefits and other approaches.

Table 11 presents a possible choice, which focuses on the building types where retrofits are the most cost-effective and which could be selected as a priority from the social point of view. Namely, if all kindergartens and hospitals in climate zone $\mathrm{C}$ will be retrofitted to the level of performance defined by the "efficiency" retrofit, the total investment required is exactly EUR 40 million.

Table 12 presents another choice of funding allocation disbursed according to the breakdown of the building floor area by building type. The budget of 40 million EUR allows retrofitting of $8 \%$ of the floor area in each building type according to the "efficiency" retrofit.

It should be understood that the success of the scheme depends not only on the allocation of financing, but also on many other factors such as the effective design of the scheme, the design of procurements, the access to capital of ESCOs given their typically small size and many others.

Table 9 Co-benefits of thermal efficiency retrofits of public buildings, the "efficiency" retrofit

\begin{tabular}{|c|c|c|c|c|c|c|c|}
\hline Analysis of co-benefits & Dormitory & Hospital & Kindergarten & Office & School & University & Total \\
\hline GDP increase, million EUR & 0.4 & 39.4 & 123.0 & 44.2 & 121.6 & 0.6 & 329 \\
\hline Labour income, million EUR & 0.2 & 18.1 & 56.4 & 20.3 & 55.8 & 0.3 & 151 \\
\hline Employment, jobs & 85 & 8963 & 27,969 & 10,048 & 27,652 & 127 & 74,844 \\
\hline $\mathrm{CO}_{2}$ avoided, million EUR & 0.02 & 4.1 & 2.4 & 1.2 & 1.2 & 0.0 & 9 \\
\hline Air quality, million EUR & 0.0 & 1.1 & 1.8 & 0.8 & 1.4 & 0.0 & 5 \\
\hline Improved comfort, million EUR & 0.1 & 4.6 & 15.2 & 5.1 & 14.8 & 0.1 & 40 \\
\hline
\end{tabular}




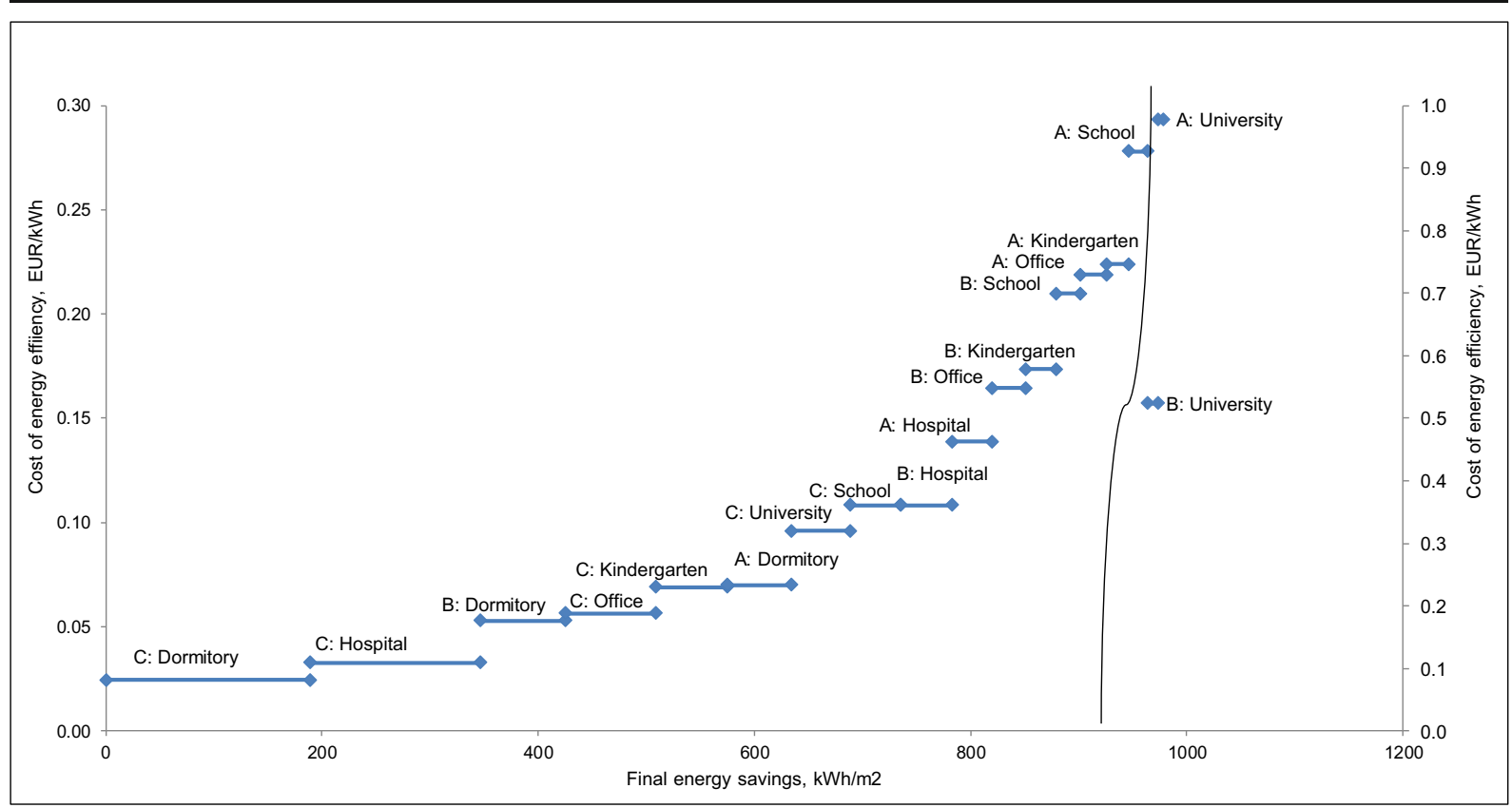

Fig. 7 Cost of energy efficiency, the "efficiency" retrofit. Note: The costs of universities in climate zones A and B have to be scaled to the right vertical axis; all other building types have to be scaled to the left vertical axis

Importance to integrate co-benefits into the analysis of energy efficiency programs

The paper illustrated a challenge of designing energy efficiency and decarbonisation policies in European economies with warm climates and low standards of living. Even though the climate is milder than in Northern Europe and the buildings' energy consumption for thermal services per square meter is respectively lower, the growing energy consumption of the building sector due to improving welfare represents an issue for energy security of the country. The largest share of thermal

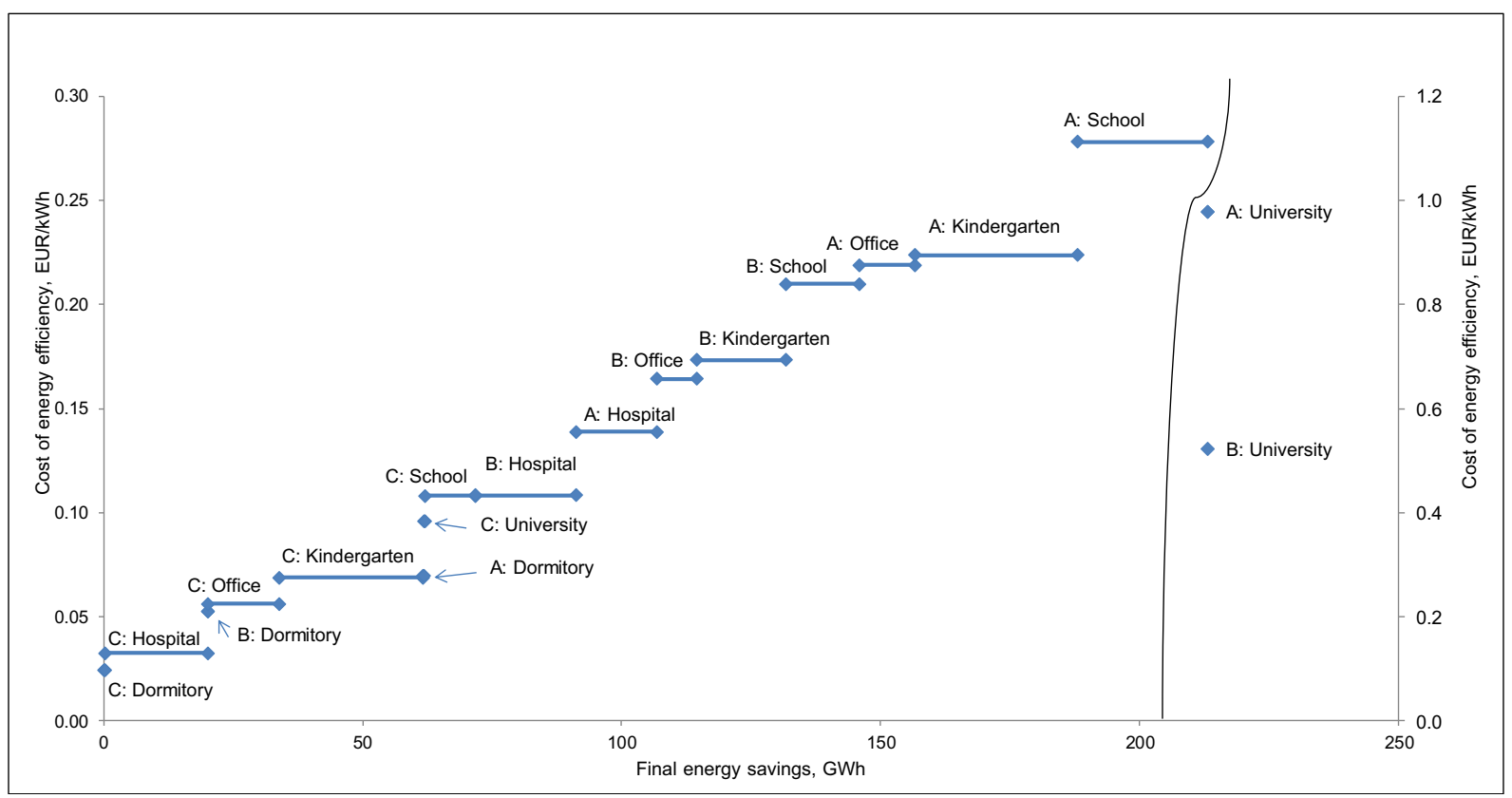

Fig. 8 Supply curve of energy efficiency, the "efficiency" retrofit 
Table 10 The initial indicative budget for funding the public sector energy efficiency (period 2017-2020)

\begin{tabular}{lc}
\hline Investment subsidies: total concessional loans, & $€ 40$ \\
commercial loans and partial credit guarantees & million \\
Other costs covered by grant funding: technical & $€ 6$ \\
$\begin{array}{lc}\text { assistance, outreach, pre-feasibility, administration, } \\
\text { and monitoring \& verification }\end{array}$ & million \\
Total budget & $€ 46$ \\
& million \\
\hline
\end{tabular}

energy services in Albania is currently addressed with domestic electricity, mostly produced at hydropower plants, and wood; however, in the future, these energy carriers will not be enough. In fact, the buildings sector and the industrial sector do already compete for energy sources in the country. The alternative carriers are those which have higher carbon content, for instance imported electricity produced at coal power plants in neighbouring countries. The traditional approach to assess the economic attractiveness of energy efficiency projects relies on the comparison of capital, installation and maintenance costs versus saved energy costs. Our calculations illustrate, however, that even though

Table 11 Retrofitting plan for the most cost-effective and socially acceptable options

\begin{tabular}{|c|c|c|}
\hline Plan characteristics & Hospitals & Kindergartens \\
\hline Floor area retrofitted, thousand $\mathrm{m}^{2}$ & 126 & 419 \\
\hline Costs of energy conserved, EUR/kWh & 0.03 & 0.07 \\
\hline Investment cost, million EUR & 10 & 30 \\
\hline $\mathrm{CO}_{2}$ reduction, $\mathrm{tCO}_{2}$ & 3.841 & 1.072 \\
\hline Primary energy demand savings, GWh & 18 & 13 \\
\hline Final energy demand savings, GWh & 20 & 28 \\
\hline $\begin{array}{l}\text { Saved energy costs, annual over } \\
\text { measure lifetime, million EUR }\end{array}$ & 3.4 & 2.0 \\
\hline Simple payback period, years & 3 & 15 \\
\hline Internal rate of return, $\%$ & 23 & 5 \\
\hline $\mathrm{NPV}, \mathrm{EUR} / \mathrm{m}^{2}$ & 46 & 5 \\
\hline Cost-benefit ratio & 0.2 & 0.9 \\
\hline GDP increase, million EUR & 6.6 & 19.3 \\
\hline Labour income, million EUR & 3.0 & 8.8 \\
\hline Employment, jobs & 1490 & 4383 \\
\hline $\begin{array}{l}\text { Monetised } \mathrm{CO}_{2} \text { emissions avoided, } \\
\text { million EUR }\end{array}$ & 1.8 & 0.5 \\
\hline $\begin{array}{l}\text { Air quality including health impacts, } \\
\text { million EUR }\end{array}$ & 0.5 & 0.7 \\
\hline $\begin{array}{l}\text { Improved comfort and services of } \\
\text { buildings, million EUR }\end{array}$ & 0.8 & 2.5 \\
\hline
\end{tabular}

building envelopes and building systems of efficiency retrofits are much better than those at the present state, the difference in energy consumption between these two is not significant. This is due to low standards of energy services currently observed in Albania, i.e. partial and intermittent heating and cooling that is much lower than health standards used elsewhere in Europe. Furthermore, in some building types, still such basic energy services are absent such as domestic hot water. The efficiency retrofit fixes these issues addressing the proper level of comfort offsetting a part of energy savings which it provides.

Therefore, for efficient policy and decision-making, it is important to make the right assumption about the amount of energy demand given these low standards of living and their improvement in the future, and it is essential to consider other benefits of energy efficiency improvement beyond saved energy costs. Thus, first it is critical to calculate energy savings not versus the status quo, but against the business-as-usual development with proper comfort levels according to European standards, as this development will define future energy consumption trends. Second, it is important to identify and assess other benefits, such as thermal comfort, avoided $\mathrm{CO}_{2}$ emissions, avoided economic effects from airborne pollutants, employment and economic growth. As illustrated, their monetised value is higher than saved energy costs that makes the importance of energy efficiency actions more evident.

Further research needs

It should be noted that the analysis presented in the paper offers many opportunities for improvement. Besides more detailed analysis of the benefits of thermal efficiency improvement, levels of comfort and others, in particular, risk and uncertainty assessment should be made. This should include the sensitivity of the key critical variables such as energy prices and key risks carried out by different stakeholders.

\section{Conclusion}

This paper developed a step-by-step methodology for the assessment of the energy-saving potential of public buildings. First, building surveys were conducted and representative types were established based on a pool of public buildings. Second, the energy demand in the 
Table 12 Retrofitting plan with funding allocation proportional to the breakdown of the building floor area by building type

\begin{tabular}{|c|c|c|c|c|c|c|c|c|}
\hline Characteristics & Units & Dorms & Hospital & Kindergarten & Offices & Schools & Universities & Total/average \\
\hline Floor area retrofitted & [thousand $\mathrm{m}^{2}$ ] & 0.7 & 61 & 202 & 68 & 197 & 0.9 & 530 \\
\hline Costs of energy conserved & [EUR/kWh] & 0.05 & 0.09 & 0.16 & 0.14 & 0.21 & 0.35 & 0.15 \\
\hline Investment cost & [million EUR] & 0.0 & 5 & 15 & 5 & 15 & 0.1 & 41 \\
\hline $\mathrm{CO}_{2}$ reduction & {$\left[\mathrm{tCO}^{2}\right]$} & 4 & 713 & 416 & 198 & 211 & 2 & 1544 \\
\hline Primary energy & [GWh] & 0.1 & 4 & 5 & 2 & 4 & 0.0 & 15 \\
\hline Final energy savings & [GWh] & 0.1 & 4 & 6 & 3 & 5 & 0.0 & 17 \\
\hline $\begin{array}{l}\text { Saved energy costs, annual over } \\
\text { measure lifetime }\end{array}$ & [million EUR] & 0.15 & 12 & 13 & 5 & 10 & 0.03 & 40 \\
\hline Simple payback & [years] & 5 & 7 & 20 & 17 & 27 & $\mathrm{~N} / \mathrm{A}$ & 17 \\
\hline Internal rate of return & {$[\%]$} & 15.7 & 11.1 & 3.0 & 4.0 & 1.1 & -0.2 & 3.9 \\
\hline NPV & {$\left[\mathrm{EUR} / \mathrm{m}^{2}\right]$} & 0.1 & 6.7 & -2.1 & 0.0 & -5.1 & 0.0 & -0.4 \\
\hline Cost-benefit ratio & & 0.3 & 0.4 & 1.2 & 1.0 & 1.5 & 2.1 & 1.0 \\
\hline GDP increase & [million EUR] & 0.03 & 3.2 & 9.8 & 3.5 & 9.7 & 0.04 & 26 \\
\hline Labour income & [million EUR] & 0.01 & 1.4 & 4.5 & 1.6 & 4.5 & 0.02 & 12 \\
\hline Employment & jobs & 6.8 & 717 & 2238 & 804 & 2212 & 10 & 5987 \\
\hline Monetised $\mathrm{CO}_{2}$ emissions avoided & [million EUR] & 0.00 & 0.3 & 0.2 & 0.1 & 0.1 & 0.00 & 1 \\
\hline Air quality including health impacts & [million EUR] & 0.00 & 0.1 & 0.1 & 0.1 & 0.1 & 0.00 & 0.4 \\
\hline $\begin{array}{l}\text { Improved comfort and services of } \\
\text { buildings }\end{array}$ & [million EUR] & 0.00 & 0.4 & 1.2 & 0.4 & 1.2 & 0.01 & 3 \\
\hline
\end{tabular}

present state was calculated and validated against measured data from energy audits; energy saving was calculated for two retrofit options. Third, the financial and economic analyses were conducted. The economic analysis made an attempt to quantify the co-benefits of energy efficiency improvements, such as thermal comfort, avoided economic effects from airborne pollutants, increase in employment and economic growth. Finally, energy efficiency supply curves were developed to illustrate the sequence of priority measures.

The goal of this approach was to support policy making in the efficient use of energy and the optimal allocation of available funds. In Albania, thermal comfort in buildings is generally lower than it is usual in the European Union, but it is expected that user behaviour will significantly change in the future with rising comfort expectations. As a result, energy use is expected to increase and not all the retrofit options will be cost-effective based on a traditional financial analysis. However, if co-benefits are monetised, their value is comparable and even higher than saved energy costs.

Acknowledgements The work is based on the information and data provided by the Albanian expert panel of the SLED project lead. The Albanian expert panel includes
Dr. Gjergji Simaku (team manager), Rodon Miraj, Teuta Thimjo, Alma Saraci, Rexhep Karapici, Elton Krito, Dashamir Çutra and Ardian Islami. We would like to express our gratitude to policy makers and experts from Albania who provided comments and data that helped us to improve the results of our work. We are grateful to the Hungarian Academy of Sciences for awarding Zsuzsa Szalay with the János Bólyai Research Scholarship, which supported her work.

Results and the determined trends are being fine-tuned and extended for other building types with a geographic scope of Hungary in another research project entitled "Large Scale Smart Meter Data Assessment for Energy Benchmarking and Occupant Behavior Profile Development of Building Clusters". Furthermore, methods and approaches developed in the current work are being further developed for large-scale data analysis.

Funding information Open access funding provided by $\mathrm{Bu}-$ dapest University of Technology and Economics. The project (no. K 128199) has been implemented with the support provided from the National Research, Development and Innovation Fund of Hungary, financed under the K_18 funding scheme. The research reported in this paper has been supported by the National Research, Development and Innovation Fund (TUDFO/51757/2019-ITM, Thematic Excellence Program). The research reported in this paper was also supported by the Higher Education Excellence Program of the Ministry of Human Capacities in the frame of Artificial Intelligence research area of Budapest University of Technology and Economics (BME FIKP-MI). 


\section{Compliance with ethical standards}

Conflict of interest The authors declare that they have no conflict of interest.

Open Access This article is licensed under a Creative Commons Attribution 4.0 International License, which permits use, sharing, adaptation, distribution and reproduction in any medium or format, as long as you give appropriate credit to the original author(s) and the source, provide a link to the Creative Commons licence, and indicate if changes were made. The images or other third party material in this article are included in the article's Creative Commons licence, unless indicated otherwise in a credit line to the material. If material is not included in the article's Creative Commons licence and your intended use is not permitted by statutory regulation or exceeds the permitted use, you will need to obtain permission directly from the copyright holder. To view a copy of this licence, visit http://creativecommons.org/licenses/by/4.0/.

\section{References}

Alves, T., Machado, L., Gonçalves, R., Souza, D., \& Wilde, P. D. (2018). Assessing the energy saving potential of an existing high-rise office building stock. Energy and Buildings, 173, 547-561. https://doi.org/10.1016/j.enbuild.2018.05.044.

Arizona State University. (2015). Green Energy-Efficient Schools for Albania. https://sustainability.asu.edu/sustainability solutions/programs/solutionsservices/albania-green-schools/. Accessed 20 June 2016.

Ballarini, I., Corrado, V., Madonna, F., Paduos, S., \& Ravasio, F. (2017). Energy refurbishment of the Italian residential building stock: energy and cost analysis through the application of the building typology. Energy Policy, 105, 148-160. https://doi.org/10.1016/j.enpol.2017.02.026.

Bidaj, F., Alushaj, R., Prifti, L., \& Chittum, A. (2015). Evaluation of the heating share of household electricity consumption using statistical analysis: a case study of Tirana, Albania. International Journal of Sustainable Energy Planning and Management, 05, 3-14. https://doi.org/10.5278 /ijsepm.2015.5.2.

Birleanu, A. M., Chavdaro, G., \& Mäkelä, T. (2013). Development of an investment programme for buildings rehabilitation: technical report on public buildings. $\mathrm{http}: / /$ heinonline backup.com/hol-cgi-bin/get_pdf.cgi?handle=hein. congrec/cbo9646\&section=1

Brøgger, M., \& Wittchen, K. B. (2018). Estimating the energysaving potential in national building stocks - a methodology review. Renewable and Sustainable Energy Reviews, 82(Part 1), 1489-1496. https://doi.org/10.1016/j.rser.2017.05.239.

Brøgger, M., Bacher, P., \& Wittchen, K. B. (2019). A hybrid modelling method for improving estimates of the average energy-saving potential of a building stock. Energy and Buildings, 199, 287-296. https://doi.org/10.1016/j. enbuild.2019.06.054.
Csoknyai, T., Hrabovszky-Horváth, S., Georgiev, Z., JovanovicPopovic, M., Stankovic, B., Villatoro, O., \& Szendrő, G. (2016). Building stock characteristics and energy performance of residential buildings in Eastern-European countries. Energy and Buildings, 132, 39-52. https://doi.org/10.1016/j. enbuild.2016.06.062.

Dall'O', G., Galante, A., \& Pasetti, G. (2012). A methodology for evaluating the potential energy savings of retrofitting residential building stocks. Sustainable Cities and Society, 4(1), 12-21. https://doi.org/10.1016/j.scs.2012.01.004.

Dascalaki, E. G., Droutsa, K. G., Balaras, C. A., \& Kontoyiannidis, S. (2011). Building typologies as a tool for assessing the energy performance of residential buildings - a case study for the Hellenic building stock. Energy and Buildings, 43(12), 3400-3409. https://doi.org/10.1016/j. enbuild.2011.09.002.

Dineen, D., Rogan, F., Gallachóir, Ó., \& B. P. (2015). Improved modelling of thermal energy savings potential in the existing residential stock using a newly available data source. Energy, 90, 759-767. https://doi.org/10.1016/j.energy.2015.07.105.

EN ISO 13790. (2008). Energy performance of buildings - calculation of energy use for space heating and cooling. https://www.iso.org/standard/41974.html. Accessed 20 June 2016.

Enti rregullator I Energjisë (online). (n.d.). Retail tariffs of electricity for the third regulatory period 2012-2014. https://www.ere.gov.al/. Accessed 20 June 2016.

European Commission. (2019). https://ec.europa. eu/commission/index_en. Accessed 20 June 2016.

EUROSTAT. (2017). Energy balances - 2015 data. https://ec. europa.eu/eurostat/web/energy/data/energy-balances. Accessed 20 June 2016.

Ferrari, S., \& Beccali, M. (2017). Energy-environmental and cost assessment of a set of strategies for retrofitting a public building toward nearly zero-energy building target. Sustainable Cities and Society, 32, 226-234. https://doi. org/10.1016/j.scs.2017.03.010.

Filogamo, L., Peri, G., Rizzo, G., \& Giaccone, A. (2014). On the classification of large residential buildings stocks by sample typologies for energy planning purposes. Applied Energy, 135, 825-835. https://doi.org/10.1016/j.apenergy. 2014.04.002.

GIZ. (2011). Capacity building for Monitoring, Verification and Evaluation (M\&V\&E System) of the energy efficiency policy in SEE countries in terms of the EU accession process. Preparation of the bottom-up $M \& V$ methodology within the project for Albania. Report prepared by B. Islami and H. Laci for the open regional fund for South East Europe energy GIZ. March -June 2011.

Global petrol prices (online). (n.d.). Albania LPG Prices. https://www.globalpetrolprices.com/. Accessed 20 June 2016.

IEA Annex 31. (2004). Methods for evaluating the environmental performance of building stocks. Energy-Related Environmental Impact of Buildings. http://www.iisbe. org/annex31/pdf/L_stock_aggregation.pdf. Accessed 20 June 2016.

Kontokosta, C. E. (2016). Modeling the energy retrofit decision in commercial office buildings. Energy and Buildings, 131, 120. https://doi.org/10.1016/j.enbuild.2016.08.062. 
Korytarova, K., \& Ürge-Vorsatz, D. (2010). Energy savings potential in the Hungarian public buildings for space heating. In IEECB'10: improving energy efficiency in commercial buildings. Frankfurt: Joint Research Centre of the European Commission.

Korytarova, K., Knapko, I., \& Šoltésová, K. (2017). Energy savings potential for space heating in public buildings in Slovakia. In Proceedings of the European Council for an Energy Efficient Economy Summer Study 2017 (pp. 13931399). https://www.eceee.org/library/conference_ proceedings/eceee_Summer_Studies/2017/6-buildingspolicies-directives-and-programmes/energy-savingspotential-for-space-heating-in-public-buildings-inslovakia/2017/6-187-17_Korytarova.pdf/. Accessed 20 June 2016.

Loga, T., Stein, B., \& Diefenbach, N. (2016). TABULA building typologies in 20 European countries - making energy-related features of residential building stocks comparable. Energy and Buildings, 132, 4-12. https://doi.org/10.1016/j. enbuild.2016.06.094.

Mata, É., Sasic Kalagasidis, A., \& Johnsson, F. (2014). Buildingstock aggregation through archetype buildings: France, Germany, Spain and the UK. Building and Environment, 81, 270-282. https://doi.org/10.1016/j.buildenv.2014 .06 .013 .

Mata, E., Medina Benejam, G., Sasic Kalagasidis, A., \& Johnsson, F. (2015). Modelling opportunities and costs associated with energy conservation in the Spanish building stock. Energy and Buildings, 88, 347-360. https://doi.org/10.1016/j. enbuild.2014.12.010.

Mikulić, D., Bakarić, I. R., \& Slijepčević, S. (2016). The economic impact of energy saving retrofits of residential and public buildings in Croatia. Energy Policy, 96(2016), 630-644. https://doi.org/10.1016/j.enpol.2016.06.040.

Novikova, A. (2008). Carbon dioxide mitigation potential in the Hungarian residential sector. Dissertation. Department of environmental sciences and policy, Central European University, Budapest. http://www.etd.ceu.edu/2009 /ephnoa01.pdf. Accessed 20 June 2016.

Novikova, A., Csoknyai, T., \& Szalay, Z. (2018). Low carbon scenarios for higher thermal comfort in the residential building sector of South Eastern Europe. Energy Efficiency, 11, 845-875. https://doi.org/10.1007/s12053-017-9604-6.

Paduos, S., \& Corrado, V. (2017). Cost-optimal approach to transform the public buildings into nZEBs: an European cross-country comparison. Energy Procedia, 140, 314-324. https://doi.org/10.1016/j.egypro.2017.11.145.

Qu, Y., Zhang, Z., Wang, H., \& Yang, F. (2017). Energy consumption analysis of public buildings located in the severe cold region. Procedia Engineering, 205, 2111-2117. https://doi.org/10.1016/j.proeng.2017.10.133.

Republic of Albania. (2003). The national strategy of energy and plan of action. http://www.akbn.gov.al/images/pdf/energjite-rinovueshme/Stategjia_Kombetare_e_Energjise.pdf. Accessed20 June 2016.
Simaku, G. (2016). Assumption provided by the Albanian expert panel of SLED project. Internal documentation of the Support for Low-Emission Development in South Eastern Europe (SLED) Project.

Simaku, G., Teuta, T., \& Thimjo, P. (2014). Performance calculation of building types. Internal documentation of the support for low-emission development in South Eastern Europe (SLED) Project.

Swan, L. G., \& Ugursal, V. I. (2009). Modeling of end-use energy consumption in the residential sector: a review of modeling techniques. Renewable and Sustainable Energy Reviews, 13(8), 1819-1835. https://doi.org/10.1016/j.rser.2008. 09.033 .

Szabo, L., Mezosi, A., Pato, Z., \& Markovic, S. (2015). Support for low-emission development in South Eastern Europe (SLED). Electricity sector modelling assessment in Albania. https://rekk.hu/analysis-details/220/support-for-lowemission-development-in-south-eastern-europe-sled. Accessed 20 June 2016.

The European Commission. (2012). Commission Delegated Regulation (EU) No 244/2012 of 16 January 2012 supplementing Directive 2010/31/EU of the European Parliament and of the Council on the energy performance of buildings by establishing a comparative methodology framework for calculating. L81 Official Journal of the European Union 19. https://eur-lex.europa. eu/LexUriServ/LexUriServ.do?uri=OJ:L:2012:081:0018 :0036:EN:PDF. Accessed 20 June 2016.

U.S. Agency for International Development. (2015). Assessment of Energy Developments in Albania for the Period 20122030. Report for the project: Low emissions strategies and clean energy development in E\&E, prepared by Center for Renewable Energy Sources and Saving (CRES) for the United States Agency for International Development (USAID). January 2015.

UNDP and Ministry of Economy Trade and Energy. (2010). PIMS 3611: The country programme of Albania under the global solar water heating market transformation and strengthening initiative.https://info.undp.org/docs/pdc/Do cuments/ALB/00050767_SWH-UNDP\%20Project\%20 Document.pdf. Accessed 20 June 2016.

Wikimedia. (2018). Map of Albania. https://commons.wikimedia. org/wiki/Category:SVG_maps_of_Albania. Accessed 20 June 2016.

World Bank (online). (2016a). Database. http://data.worldbank. org/. Accessed 20 June 2016.

World Bank (online). (2016b). World Bank commodities price forecast (constant US dollars). https://www.worldbank. org/en/research/commodity-markets. Accessed 20 June 2016.

Publisher's note Springer Nature remains neutral with regard to jurisdictional claims in published maps and institutional affiliations. 